\title{
Survival of patients with non-small cell lung cancer having leptomeningeal metastases treated with immune checkpoint inhibitors
}

Citation for published version (APA):

Hendriks, L. E. L., Bootsma, G., Mourlanette, J., Henon, C., Mezquita, L., Ferrara, R., Audigier-Valette, C., Mazieres, J., Lefebvre, C., Duchemann, B., Cousin, S., le Pechoux, C., Botticella, A., De Ruysscher, D., Dingemans, A-M. C., \& Besse, B. (2019). Survival of patients with non-small cell lung cancer having leptomeningeal metastases treated with immune checkpoint inhibitors. European Journal of Cancer, 116, 182-189. https://doi.org/10.1016/j.ejca.2019.05.019

Document status and date:

Published: 01/07/2019

DOI:

10.1016/j.ejca.2019.05.019

Document Version:

Publisher's PDF, also known as Version of record

Document license:

Taverne

Please check the document version of this publication:

- A submitted manuscript is the version of the article upon submission and before peer-review. There can be important differences between the submitted version and the official published version of record.

People interested in the research are advised to contact the author for the final version of the publication, or visit the DOI to the publisher's website.

- The final author version and the galley proof are versions of the publication after peer review.

- The final published version features the final layout of the paper including the volume, issue and page numbers.

Link to publication

\footnotetext{
General rights rights.

- You may freely distribute the URL identifying the publication in the public portal. please follow below link for the End User Agreement:

www.umlib.nl/taverne-license

Take down policy

If you believe that this document breaches copyright please contact us at:

repository@maastrichtuniversity.nl

providing details and we will investigate your claim.
}

Copyright and moral rights for the publications made accessible in the public portal are retained by the authors and/or other copyright owners and it is a condition of accessing publications that users recognise and abide by the legal requirements associated with these

- Users may download and print one copy of any publication from the public portal for the purpose of private study or research.

- You may not further distribute the material or use it for any profit-making activity or commercial gain

If the publication is distributed under the terms of Article $25 f a$ of the Dutch Copyright Act, indicated by the "Taverne" license above, 


\title{
Survival of patients with non-small cell lung cancer having leptomeningeal metastases treated with immune checkpoint inhibitors
}

\author{
Lizza E.L. Hendriks a,b,*, Gerben Bootsma ${ }^{c}$, Jean Mourlanette ${ }^{d}$, \\ Clemence Henon ${ }^{a}$, Laura Mezquita ${ }^{a}$, Roberto Ferrara ${ }^{a}$, \\ Clarisse Audigier-Valette ${ }^{\mathrm{e}}$, Julien Mazieres ${ }^{\mathrm{d}}$, Corentin Lefebvre ${ }^{\mathrm{d}}$, \\ Boris Duchemann ${ }^{\mathrm{f}}$, Sophie Cousin ${ }^{\mathrm{g}}$, Cecile le Pechoux ${ }^{\mathrm{h}}$, \\ Angela Botticella ${ }^{\mathrm{h}}$, Dirk De Ruysscher ${ }^{\mathrm{i}}$, Anne-Marie C. Dingemans ${ }^{\mathrm{b}}$, \\ Benjamin Besse ${ }^{a, j}$
}

\footnotetext{
a Department of Medical Oncology, Gustave Roussy Cancer Campus, Institut d'Oncologie Thoracique (IOT), Gustave Roussy, Université Paris-Saclay, F-94805, Villejuif, France

${ }^{\mathrm{b}}$ Department of Pulmonary Diseases, GROW-School for Oncology and Developmental Biology, Maastricht University Medical Center+, Maastricht, the Netherlands

${ }^{\mathrm{c}}$ Department of Pulmonary Diseases, Zuyderland Hospital, Location Heerlen, the Netherlands

${ }^{\mathrm{d}}$ Department of Pulmonary Diseases, Centre Hospitalier Universitaire de Toulouse, Université Paul Sabatier, Toulouse, France

${ }^{\mathrm{e}}$ Department of Pulmonary Diseases, Centre Hospitalier Toulon Sainte-Musse, Toulon, France

${ }^{\mathrm{f}}$ Department of Pulmonary Diseases, Hopital Avicenne, Paris, France

${ }^{\mathrm{g}}$ Department of Medical Oncology, Institut Bergonie, Bordeaux, France

${ }^{\mathrm{h}}$ Department of Radiation Oncology, Gustave Roussy Cancer Campus, Villejuif, France

${ }^{i}$ Department of Radiation Oncology (MAASTRO Clinic), GROW School for Oncology and Developmental Biology, Maastricht University Medical Center+, Maastricht, the Netherlands

${ }^{\mathrm{j}}$ Paris-Sud University, Orsay, France
}

Received 15 March 2019; received in revised form 4 May 2019; accepted 12 May 2019 Available online 13 June 2019

\footnotetext{
* Corresponding author: Dept. of Pulmonary Diseases Maastricht University Medical Center+, PO Box 5800, 6202, AZ, Maastricht, the Netherlands. Fax: +310433875051

E-mail addresses: lizza.hendriks@mumc.nl (L.E.L. Hendriks), G.bootsma@zuyderland.nl (G. Bootsma), Jean.mourlanette@orange.fr(J. Mourlanette), clemence.HENON@gustaveroussy.fr(C.Henon), laura.MEZQUITA@gustaveroussy.fr (L. Mezquita), Roberto.Ferrara@ istitutotumori.mi.it (R. Ferrara), Clarisse.Audigier-Valette@ch-toulon.fr (C. Audigier-Valette), mazieres.j@chu-toulouse.fr (J. Mazieres), corentin.lefebvre@hotmail.com (C. Lefebvre), Boris.duchemann@aphp.fr (B. Duchemann), s.cousin@bordeaux.unicancer.fr (S.Cousin), Cecile. LEPECHOUX@gustaveroussy.fr (C. le Pechoux), angela.BOTTICELLA@gustaveroussy.fr (A. Botticella), Dirk.deruysscher@maastro.nl (D. De Ruysscher), a.dingemans@mumc.nl (A.-M.C. Dingemans), Benjamin.BESSE@gustaveroussy.fr (B. Besse).
} 


\section{KEYWORDS}

NSCLC;

Immune checkpoint

inhibition;

Leptomeningeal

metastases

\begin{abstract}
Introduction: Patients with non-small cell lung cancer (NSCLC) experience leptomeningeal metastases (LM) in 3-9\% of cases. Because overall survival (OS) and performance status are very poor, they are mostly excluded from clinical trials. Here, we evaluated survival of patients with NSCLC having LM treated with immune checkpoint inhibitors (ICIs).

Methods: A prospectively collected list of patients with advanced NSCLC treated with ICIs between November 2012 and July 2018 in 7 European centres was merged. All patients with LM before ICI start were selected, data were retrospectively added and patients were classified according to the National Comprehensive Cancer Network (NCCN) LM prognostic classification (good/poor). Progression-free survival (PFS) and OS on ICIs were evaluated.

Results: Nineteen of $1288(1.5 \%)$ patients had LM; 73.7\% had synchronous brain metastases; $73.7 \%$ had neurological symptoms at the start of ICIs and 52.6\% were in the NCCN LM good prognosis group. Programmed death ligand-1 (PD-L1) expression was known for $42.1 \%$ of patients $(87.5 \%$ positive). Median follow-up was 13 months from the start of ICIs, and median (95\% confidence interval [CI]) PFS on ICIs was $2.0(1.8-2.2)$ months. Six-month PFS rate was $21.0 \%$ and was significantly higher in the NCCN good versus poor prognostic group: $40 \%$ vs $0 \%(\mathrm{p}=0.05)$. Twelve-month PFS rate was $0 \%$. Median $(95 \% \mathrm{CI}) \mathrm{OS}$ from the start of ICIs was $3.7(0.9-6.6)$ months. Six-month OS rate was $36.8 \%$, and 12 -month OS rate was $21.1 \%$; both were not statistically significantly different for the good versus poor NCCN prognostic group ( $\mathrm{p}=0.40$ and $\mathrm{p}=0.56$, respectively).
\end{abstract}

Conclusion: Some patients with NSCLC having LM do benefit from ICI treatment; specifically, those in the NCCN LM good prognosis group can obtain a long survival.

(c) 2019 Elsevier Ltd. All rights reserved.

\section{Introduction}

Leptomeningeal metastases (LM) are diagnosed in up to $9 \%$ of patients with non-small cell lung cancer (NSCLC) [1,2]. Diagnosis is based on clinical evaluation, typical findings on brain/spinal cord magnetic resonance imaging (MRI) and presence of tumour cells in the cerebrospinal fluid (CSF) $[3,4]$. The National Comprehensive Cancer Network (NCCN) guideline advises to classify patients according to poor or good risk (Supplemental Table 1) and recommends best supportive care (BSC) for the poor risk group [3]. The European Association of NeuroOncology (EANO)-European Society for Medical Oncology (ESMO) guideline advises BSC in those with an expected survival of less than one month [4]. Treatment for patients with better prognosis consists of (combinations of) radiotherapy and systemic therapy with/without intrathecal chemotherapy $[3,4]$. Despite treatment, the median overall survival (OS) is 1-3 months for patients without, and up to 12 months for patients with, a targetable molecular alteration [5,6]. Immune checkpoint inhibitor (ICI) therapy has revolutionised the treatment for patients with NSCLC and has become standard of care in locally advanced and metastatic disease [7,8]. However, all NSCLC ICI trials have excluded patients with LM; hence, only a few case reports are available $[9,10]$. Two phase II trials included patients with only melanoma or mainly breast cancer $[11,12]$. To obtain more data on survival of patients with NSCLC having LM treated by ICI therapy, we performed a multicenter data collection.

\section{Patients and methods}

A prospectively collected list of patients with advanced NSCLC treated with ICIs between November 2012 and July 2018 in seven European centres (five French and two Dutch) was merged. All consecutive patients with advanced NSCLC were included when they were treated with programmed death ligand-1 (PD-L1) inhibitors with or without anti-cytotoxic T-lymphocyte antigen-4 (CTLA4) within routine clinical care, expanded access/ compassionate use programs and clinical trials. Medical records were screened, and all patients diagnosed with LM (based on positive CSF analysis and/or imaging) before the start of ICIs were included. LM were classified according to EANO-ESMO criteria (Supplemental Table 2) [4].

Demographics, clinical, pathological/molecular and survival data were retrospectively extracted from the medical records between October 2018 and December 2018. PD-L1 expression was assessed on tumour cells by immunohistochemistry in each local institution. Expression of at least $1 \%$ was considered positive. Radiological assessments of the brain and extracranial disease were performed at discretion of the treating physician (usually every six to nine weeks), and response was determined locally at each institution by the 
investigator. Patients were classified as poor or good prognosis according to the NCCN criteria (Supplemental Table 1) [3].

This study was approved by the Institutional Review Board of Gustave Roussy (Commission Scientifique des Essais Thérapeutiques) and the ethical committee of Maastricht University Medical Center+ (number 2018-0805): informed consent was considered not necessary by the ethics committee.

\subsection{Statistical analysis}

OS was calculated from the date of the first ICI administration until death due to any cause. Progression-free survival (PFS) was calculated from the date of the first ICI administration until progressive disease (PD: cranial and/or extracranial or symptomatic when imaging was not available), or death due to any cause. Statistics were performed using SPSS (IBM statistics, version 23). Descriptive statistics of demographic and clinical variables were obtained. Six- and 12-month PFS and OS rates were compared for different groups using the Fisher exact test. Survival curves were estimated using the Kaplan-Meier method.

\section{Results}

\subsection{Patient selection and characteristics of patients with leptomeningeal metastases}

Data of 1288 patients with NSCLC treated with ICIs were screened. Nineteen $(1.5 \%)$ had LM (with/without brain metastases) at the start of ICI therapy (Table 1): mean age was 59.3 years (range, 41.1-69.1), 13 (68.4\%) were female, $17(89.5 \%)$ had adenocarcinoma and eight (42.1\%) had known PD-L1 status (7/8 positive, PD-L1 expression level: 20-95\%). Six patients had a targetable driver mutation (3 EGFR, 1 ALK, 1 BRAF, 2 MET); all these patients received ICI after exhaustion of targeted therapies. Fourteen $(73.7 \%)$ patients had brain metastases also, and $14(73.7 \%)$ had neurological symptoms at the start of ICI therapy (varying from slight headache to severe neurological symptoms). Ten out of $19(52.6 \%)$ were in the good prognostic NCCN LM group. Details on LM diagnosis, treatment and symptoms and PFS/OS per patient are depicted in Table 2. Patient 3 (also reported previously) [10] was treated with intrathecal methotrexate before the start of ICIs, and patient 17 received intrathecal methotrexate concurrent with nivolumab.

\subsection{Outcome}

Time from LM diagnosis to the start of ICI therapy ranged from 0 to 16.6 months: for five and eight patients, respectively, LM diagnosis was within one and $\geq$ six months of the start of ICI therapy (Fig. 1). Median follow-up from the start of ICI therapy was 13 months. Except for one patient (patient 13, died of trauma), all patients showed disease progression. The clinical condition of three patients deteriorated very rapidly; they died before brain or extracranial imaging could be performed. For one patient, the neurological condition improved, nine deteriorated (Table 2). Seven patients

Table 1

Patient characteristics.

\begin{tabular}{|c|c|c|c|c|c|c|c|c|}
\hline$\overline{\mathrm{Nr}}$ & $\begin{array}{l}\text { Age at the } \\
\text { start of ICI } \\
\text { therapy, years }\end{array}$ & Gender & $\begin{array}{l}\text { Smoking } \\
\text { status/PY }\end{array}$ & $\begin{array}{l}\text { Histology/molecular } \\
\text { status }\end{array}$ & $\begin{array}{l}\text { PD-L1 } \\
\text { status/antibody }\end{array}$ & $\begin{array}{l}\mathrm{Nr} \text { of organs } \\
\text { with metastases at } \\
\text { the start of ICI therapy }\end{array}$ & $\begin{array}{l}\text { ICI treatment } \\
\text { line }\end{array}$ & Type of ICI \\
\hline 1 & 68.1 & $\mathrm{~F}$ & Former/40 & SCC/unk & unk & 3 & 3 & Nivolumab \\
\hline 2 & 65.8 & $\mathrm{~F}$ & Former/35 & $\mathrm{AC} / K R A S$ & $20 \% / 28$ & 2 & 3 & Pembrolizumab \\
\hline 3 & 53.6 & M & Former/35 & $\mathrm{AC} / K R A S$ & unk & 3 & 2 & Nivolumab \\
\hline 4 & 63.5 & $\mathrm{~F}$ & Unk/unk & $\mathrm{AC} / K R A S$ & $80 \% / 22 \mathrm{C} 3$ & 3 & 2 & Pembrolizumab \\
\hline 5 & 69.1 & $\mathrm{M}$ & Former/20 & $\mathrm{AC} / A L K$ & unk & 3 & 4 & Nivolumab \\
\hline 6 & 52.0 & $\mathrm{~F}$ & Former/7 & $\mathrm{AC} / E G F R$ & 0/unk & 5 & 4 & Nivolumab \\
\hline 7 & 55.3 & $\mathrm{~F}$ & Unk/unk & $\mathrm{AC} / E G F R$ & Pos $/ 22 \mathrm{C} 3$ & 3 & 5 & Pembrolizumab \\
\hline 8 & 55.3 & $\mathrm{~F}$ & Current/30 & $\mathrm{AC} / K R A S$ & unk & 6 & 2 & Nivolumab \\
\hline 9 & 51.0 & $\mathrm{~F}$ & Former/15 & $\mathrm{AC} / M E T$ & $80 \% / 28$ & 2 & 5 & Pembrolizumab \\
\hline 10 & 41.1 & M & Former/15 & $\mathrm{AC} / \mathrm{WT}$ & unk & 4 & 3 & Nivolumab \\
\hline 11 & 66.4 & $\mathrm{~F}$ & Former $/ 50$ & $\mathrm{AC} / \mathrm{WT}$ & $95 \% / 22 \mathrm{C} 3$ & 4 & 2 & Pembrolizumab \\
\hline 12 & 65.4 & $\mathrm{M}$ & Former/unk & AC/WT & $90 \% / 28$ & 2 & 2 & Pembrolizumab \\
\hline 13 & 56.8 & $\mathrm{~F}$ & Current/40 & AC/WT & unk & 3 & 2 & Nivolumab \\
\hline 14 & 69.1 & $\mathrm{~F}$ & Never & $\mathrm{AC} / E G F R$ & unk & 3 & 7 & Nivolumab \\
\hline 15 & 66.0 & $\mathrm{~F}$ & Former/unk & AC/WT & unk & 6 & 2 & Nivolumab \\
\hline 16 & 52.2 & $\mathrm{~F}$ & Current/unk & $\mathrm{AC}, \mathrm{WT}$ & unk & 5 & 2 & Nivolumab \\
\hline 17 & 53.6 & $\mathrm{~F}$ & Current/20 & $\mathrm{AC} / B R A F$ & $80 \% /$ unk & 3 & 3 & Nivolumab \\
\hline 18 & 57.2 & M & Current/40 & SCC/unk & unk & 5 & 2 & Nivolumab \\
\hline 19 & 64.8 & M & Current/35 & $\mathrm{AC} / E G F R \mathrm{ampl}$ & unk & 7 & 6 & Nivolumab \\
\hline
\end{tabular}

Abbreviations: nr: number; ICI: immune checkpoint inhibitor; PY: packyears; PD-L1: programmed death ligand-1; F: female; M: male; SCC: squamous cell carcinoma; AC: adenocarcinoma; KRAS: Kirsten rat sarcoma viral antigen; EGFR: epidermal growth factor receptor; BRAF: vRAF murine sarcoma viral oncogene homologue B; ampl: amplification; unk: unknown. 
Table 2

Leptomeningeal metastases details and PFS and OS from immune checkpoint inhibitor initiation per patient.

\begin{tabular}{|c|c|c|c|c|c|c|c|c|c|c|c|c|c|c|c|}
\hline $\mathrm{Nr}$ & LP/results & $\begin{array}{l}\text { MRI } \\
\text { brain }^{a}\end{array}$ & $\begin{array}{l}\text { EANO-ESMO } \\
\text { diagnosis group }\end{array}$ & $\begin{array}{l}\text { BM at the } \\
\text { start of ICI } \\
\text { therapy }\end{array}$ & $\begin{array}{l}\text { Cranial } \\
\text { rtx before } \\
\text { ICI }\end{array}$ & $\begin{array}{l}\text { Time from } \\
\text { cranial } \\
\text { rtx to ICI, } \\
\text { months }\end{array}$ & $\begin{array}{l}\text { Time from } \\
\text { LM diagnosis } \\
\text { to the start of } \\
\text { ICI therapy, } \\
\text { months }\end{array}$ & $\begin{array}{l}\text { KPS at } \\
\text { the start } \\
\text { of ICI } \\
\text { therapy }\end{array}$ & $\begin{array}{l}\text { MRI brain } \\
\text { baseline } \\
\text { ICI/follow-up } \\
\text { ICI }\end{array}$ & $\begin{array}{l}\text { LM symptomatic at } \\
\text { the start of ICI } \\
\text { therapy/symptoms }\end{array}$ & $\begin{array}{l}\text { Use of } \\
\text { steroids/dose } \\
\text { prednisolone } \\
\text { per day }\end{array}$ & $\begin{array}{l}\text { NCCN } \\
\text { risk } \\
\text { group }\end{array}$ & $\begin{array}{l}\text { Neurological } \\
\text { status during } \\
\text { ICI }\end{array}$ & $\begin{array}{l}\text { ICI PFS, } \\
\text { months }\end{array}$ & $\begin{array}{l}\text { ICI OS, } \\
\text { months }\end{array}$ \\
\hline 1 & No & Yes & IIB probable & No & Yes & 0.5 & 1.2 & 100 & Yes/yes & No & No & Good & Stable & 10.4 & $11.6+$ \\
\hline 2 & Yes/neg & Yes & IIB probable & No & No & N/A & 16.6 & 80 & No/yes & $\begin{array}{l}\text { Yes/visual } \\
\text { disturbances }\end{array}$ & Yes/10 mg & Good & Stable & 7.3 & $13.0+$ \\
\hline 3 & Yes/pos & Yes & $1 \mathrm{~A}$ & Yes & No & N/A & 8.5 & 80 & Yes/no & Yes/facialis paralysis & Yes/20 mg & Good & Improve & 6.4 & 10.7 \\
\hline 4 & No & $\begin{array}{l}\text { No } \\
\text { (PET-CT) }\end{array}$ & IIunk probable & Yes & Yes & $18.9(\mathrm{BM})$ & 15.8 & 90 & Yes/no & Yes/headache & No & Good & Stable & 6.1 & $12.9+$ \\
\hline 5 & Yes/pos & Yes & IC & No & No & N/A & 2.3 & 80 & Yes/no & $\begin{array}{l}\text { Yes/light headache, } \\
\text { vertigo }\end{array}$ & No & Good & Worse & 2.8 & 3.7 \\
\hline 6 & Yes/neg & Yes & IIB probable & Yes & Yes & $5.6(\mathrm{BM})$ & 4.0 & 70 & $\mathrm{No} / \mathrm{no}$ & $\begin{array}{l}\text { Yes/visual } \\
\text { disturbances, } \\
\text { nausea, vomiting }\end{array}$ & No & Poor & Stable & 2.5 & 10.6 \\
\hline 7 & Yes/neg & Yes & IIB probable & Yes & No & N/A & $0 . .2$ & 90 & Yes/no & $\begin{array}{l}\text { Yes/sensory } \\
\text { disturbances upper } \\
\text { extremities }\end{array}$ & No & Good & Stable & 2.1 & 15.6 \\
\hline 8 & No & Yes & IIA probable & Yes & Yes & 0 & 0.1 & 60 & Yes/no & $\begin{array}{l}\text { Yes/headache, } \\
\text { nausea }\end{array}$ & Yes/unk & Poor & Worse & 2.0 & 2.0 \\
\hline 9 & Yes/pos & Yes & IA & Yes & Yes & 1.6 & 1.6 & 80 & Yes/no & $\begin{array}{l}\text { Yes/sensory loss } \\
\text { toes, pain legs }\end{array}$ & Yes/20 mg & Good & Worse & $1.9^{\mathrm{d}}$ & 2.0 \\
\hline 10 & Yes/pos & Yes & IB & Yes & Yes & 5.5 & 7.6 & 50 & Yes/no & $\begin{array}{l}\text { Yes/visual } \\
\text { disturbances, } \\
\text { dysartria, absences }\end{array}$ & Yes/80 mg & Poor & Worse & 1.8 & 2.5 \\
\hline 11 & No & Yes & IIA probable & Yes & Yes & 5.5 & 6.0 & 80 & Yes/no & Yes/light headache & Yes $/ 1.5 \mathrm{mg}$ & Good & Stable & 1.8 & 4.0 \\
\hline 12 & Yes/pos & Yes & IB & Yes & Yes & 1.2 & 6.1 & 80 & $\mathrm{No} /$ no & $\begin{array}{l}\text { Yes/headache, } \\
\text { vomiting, hearing } \\
\text { loss, walking } \\
\text { problems }\end{array}$ & Yes/100 mg & Poor & Worse & $1.7^{\mathrm{d}}$ & 1.8 \\
\hline 13 & No & Yes & IIB probable & Yes & Yes & 0.1 & 0.1 & 60 & Yes/yes & $\begin{array}{l}\text { Yes/facialis } \\
\text { paralysis, headache, } \\
\text { cerebellar symptoms }\end{array}$ & No & Poor & Stable & 1.7 & $1.7^{\mathrm{e}}$ \\
\hline 14 & No & Yes & IIB probable & Yes & Yes & $9.1(\mathrm{BM})$ & 1.2 & 70 & Yes/yes & No & Yes/40 mg & Good & Worse & 1.7 & 5.8 \\
\hline 15 & No & Yes & IIA probable & Yes & Yes & 0.7 & 1.3 & 70 & No/no & Yes/severe headache & No & Poor & Worse & 0.9 & 1.7 \\
\hline 16 & No & Yes & IIC probable & Yes & Yes & 12.0 & 12.5 & 60 & Yes/no & No & No & Poor & $\begin{array}{l}\text { Stable } \\
\text { (cont }\end{array}$ & $\begin{array}{l}0.8^{\mathrm{d}} \\
\text { tinued on ne }\end{array}$ & $\begin{array}{l}0 . .9 \\
\text { ext page) }\end{array}$ \\
\hline
\end{tabular}




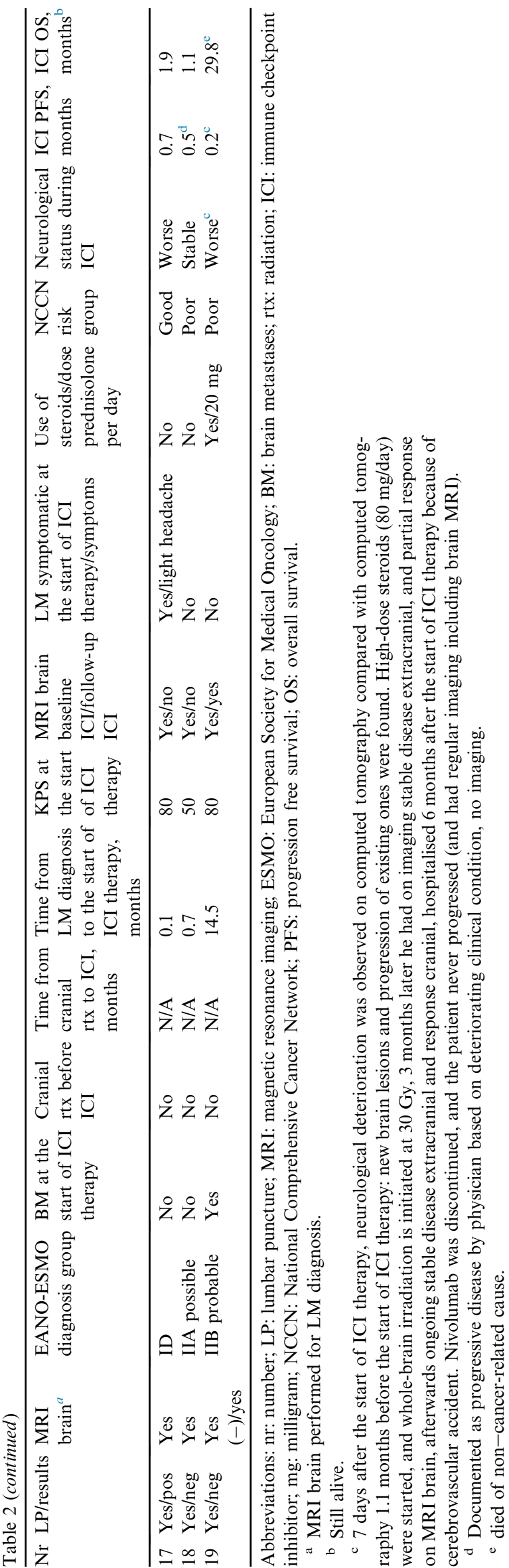

had baseline and follow-up brain imaging (five had MRI follow-up): three had progressive central nervous system disease (PD) as the best cranial response (two stable disease (SD) extracranial and 1 PD extracranial) and 2 SD. The two patients with SD as the best LM response did not experience LM PD on MRI during follow-up but had extracranial PD.

Median (95\% confidence interval [CI]) PFS on ICIs was $2.0(1.8-2.2)$ months. Six-month PFS rate was $21.0 \%$ (4/19 patients, $95 \% \mathrm{CI}: 1-41 \%)$ and was significantly higher for the NCCN LM good versus poor prognostic group (40\% [95\% CI: 3-77\%] vs 0\% [95\% CI: not evaluable (NE)], $\mathrm{p}=0.05$ ). Twelve-month PFS rate was $0 \%$. Survival curves are depicted inFig. 2A. Five patients were treated with ICIs for $\geq$ six months, four of whom were in the good prognostic group. None of the patients treated with $\geq$ six months of ICIs had a targetable driver mutation. PD-L1 status was known only for two $(20 \%$ and $80 \%$, respectively). The five others who were PD-L1 positive all progressed within $0.7-2$ months.

Except for three patients, all died. Median OS from LM diagnosis was 10.0 (95\% CI: 5.6-14.3) months. Median OS from the start of ICI therapy was $3.7(95 \%$ CI: 0.9-6.6) months (Fig. 2B). Six-month OS from the start of ICI therapy was $36.8 \%$ (7/19 patients, 95\% CI: $13-61 \%$ ), and 12 -month OS was $21.1 \%$ (4/19 patients, $95 \%$ CI: $1-41 \%$ ); both were not statistically significantly different for the poor versus good NCCN prognostic group ( $\mathrm{p}=0.22$ and $\mathrm{p}=0.33$, respectively). Two out of four patients with $\geq 12$-month survival had a PFS on ICI therapy for $\geq 6$ months; three were PD-L1 positive (other unknown). Three received another line of systemic treatment.

\section{Discussion}

Data on survival of patients with NSCLC having LM treated with ICIs are scarce. To the best of our knowledge, with 19 included patients, we report here the largest, detailed multicentre series to date. Because ICI efficacy is so far unknown for LM, most of them received ICIs when alternatives were no longer available. In general, survival was poor, although some patients, especially those with an NCCN good prognosis classification, benefited from ICI treatment (6month PFS $21.0 \%, 40 \%$ versus $0 \%$ for good versus poor prognosis classification). Furthermore, some patients with LM can obtain a relatively long survival (also after PD on ICI therapy) because 6- and 12-month OS rates were $36.8 \%$ and $21.1 \%$, respectively. The median OS was comparable to a single-arm phase II pembrolizumab trial, including 20 patients with LM (1 NSCLC; 3.7 vs 3.6 months), but 6-month $(22.0 \%)$ and 12 -month OS $(0 \%)$ rates were lower than our data [11]. Compared with our data, a similar median (5.1 months), six- (43.8\%) and 12-month (31.3\%) OS rates 


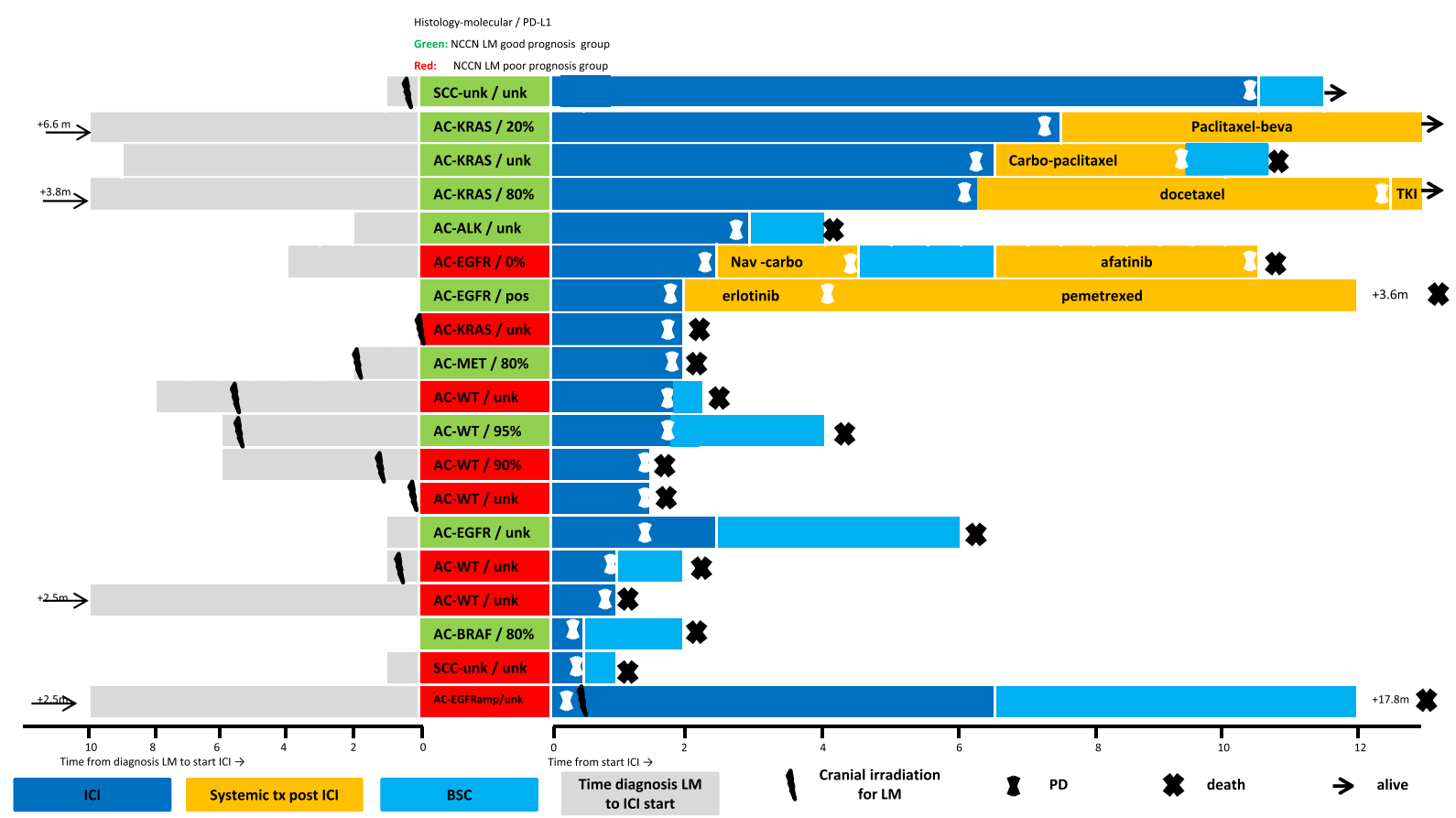

Fig. 1. Swimmer plot of patients with NSCLC having leptomeningeal metastases treated with immune checkpoint inhibitors. Abbreviations: PD-L1: programmed death-ligand 1; NCCN: National Comprehensive Cancer Network; LM: leptomeningeal metastases; SCC: squamous cell carcinoma; unk: unknown; AC: adenocarcinoma; KRAS: Kirsten rat sarcoma viral antigen mutation; beva: bevacizumab; carbo: carboplatin; TKI: tyrosine kinase inhibitor; ALK: anaplastic lymphoma kinase translocation; nav: navelbin; m: months; EGFR: epidermal growth factor receptor mutation; WT: wild type; BRAF: v-raf murine sarcoma viral oncogene homologue B; amp: amplification; ICI: immune checkpoint inhibitor; tx: therapy; BSC: best supportive care; PD: progressive disease; NE: not evaluable.
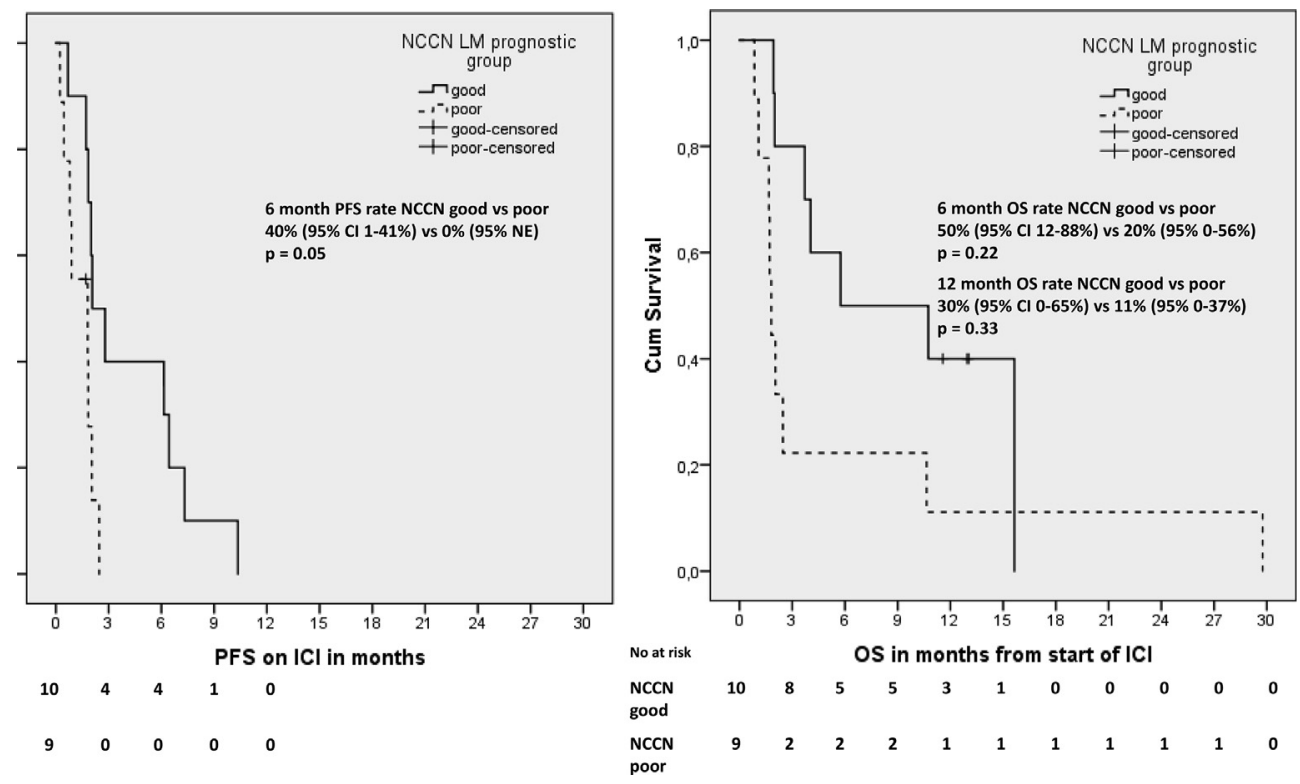

Fig. 2. (A) Progression-free survival on immune checkpoint inhibitor therapy; (B) overall survival from the start of immune checkpoint inhibitor therapy. Abbreviations: NCCN: National Comprehensive Cancer Network; LM: leptomeningeal metastases; PFS: progressionfree survival; ICI: immune checkpoint inhibitor; OS: overall survival.

were found in a melanoma nivolumab trial in the cohort with progressing and/or symptomatic brain metastases, and/or LM [12]. A retrospective series including 25 patients with melanoma having LM, 10 of whom were treated with the CTLA4 inhibitor ipilimumab, showed survivals from diagnosis of LM ranging from 1.4 to 54.2 months for patients treated with ipilimumab (ipilimumab treatment was often preceded or followed by BRAF-inhibition and/or whole brain radiotherapy (WBRT)) [13]. 
Because $73.7 \%$ had neurological symptoms at the start of ICI therapy and only five patients underwent followup brain MRI during ICI treatment, differentiation between ICI toxicity and brain/LM progression was difficult. In the phase II trials reported to date with mainly patients with breast cancer and melanoma, toxicity was usually low grade and manageable. Headache was the most common neurological grade 3 toxicity in six and $10 \%$, respectively $[11,12]$. In the present study, not all patients had a lumbar puncture for CSF analysis, although all patients with only imaging available had symptoms suggestive of LM. Furthermore, it is possible that some patients with LM were missed when screening the total ICI database because some could have had asymptomatic LM that were invisible on MRI before ICI therapy. Other drawbacks are inherent to the retrospective data collection (although the overview of patients receiving ICI was prospectively collected), making Response assessment in neuro-oncology (RANO) response evaluation [14] not feasible. All patients could be classified as having good or poor risk, but PD-L1 status (associated with outcome on ICI) was not available for all. The included population was heterogeneous (e.g. different previous treatments, driver mutations), making comparisons across groups more difficult.

Trials specifically evaluating patients with LM are often difficult to perform because the clinical condition of these patients often deteriorates rapidly, and the population is very heterogeneous. Currently, several early-phase ICI trials for patients with LM are ongoing, addressing PD-L1 inhibition (intravenous or intrathecal) with or without CTLA4 inhibition or radiotherapy (Supplemental Table 3). Because first-line ICI combined with chemotherapy proved superior to chemotherapy alone [15], it would be interesting to evaluate this combination in patients with LM.

\section{Conclusion}

In conclusion, most patients with NSCLC having LM do not benefit from ICI treatment, although some, especially those in the NCCN LM good prognosis group, can obtain a long survival.

\section{Conflicts of interest statement}

L.E.L.H. has received research funding from Roche and Boehringer Ingelheim; has been a member of the advisory board of Boehringer Ingelheim and BristolMyers Squibb (BMS), (both institution and self), has received travel/conference reimbursement from Roche and BMS (self); has been part of a mentorship program with key opinion leaders funded by AstraZeneca; has received fees for educational webinars Quadia (self). and reports no conflict of interest related to this work. L.M. has been a member of the speakers' bureau of BMS and a member of the advisory board of Roche diagnostics. C $\mathrm{A}-\mathrm{V}$. has been the principal investigator of industry trials (AstraZeneca, Boehringer Ingelheim, BMS, Novartis and Roche) and has been a member of the advisory board of AstraZeneca, Boehringer Ingelheim, BMS, Eli Lilly, Novartis, MSD, Pfizer and Roche and speakers' bureau of AstraZeneca, Boehringer Ingelheim, BMS, Eli Lilly, Novartis, Pfizer and Roche. J.M. has received institutional research funding from Roche, BMS and AstraZeneca; has served consulting/advisory roles for Novartis, Roche/Genentech, Pfizer, BMS, Lilly and ImClone Systems, MSD and AstraZeneca; and has received travel/accommodation fees from Pfizer, Roche and BMS. C.1.P. has been a member of the advisory board of AstraZeneca and reports no conflict of interest related to this work. D.D.R. has been a member of the advisory board of BMS, AstraZeneca, Roche/Genentech, Merck/Pfizer and Celgene; has received research grants from AstraZeneca, BMS and Boehringer Ingelheim. All income from the advisory board and from the research grants went integrally to the institution. A.-M.C.D. has been a member of the advisory board of BMS, MSD, Roche, Eli Lilly, Takeda, Pfizer and Boehringer Ingelheim and has received research grant from BMS (institution). BD has given expert testimony to BMS and Roche (payment to self) and has received travel and accommodation fees from BMS and Roche (payment to self).. ).B.B. has received institutional grants for clinical and translational research from AbbVie, Amgen, AstraZeneca, Biogen, Blueprint Medicines, BMS, Celgene, Eli Lilly, GSK, Ignyta, Ipsen, Merck KGaA, MSD, Nektar, Onxeo, Pfizer, Pharma Mar, Sanofi, Spectrum Pharmaceuticals, Takeda and Tiziana Pharma and has no conflict of interest related to this work. G.B., C.H., R.F., C.L. S.C., A.B., and J Mourlanette (JM = Julien Mazieres) have no conflict of interest to declare.

\section{Funding}

L.E.L.H. was the recipient of a DUERTECC/ EURONCO grant for 2017-2018.

\section{Writing assistance}

None.

\section{Data statement}

Not publicly available (retrospective database collection).

\section{Appendix A. Supplementary data}

Supplementary data to this article can be found online at https://doi.org/10.1016/j.ejca.2019.05.019. 


\section{References}

[1] Remon J, Le Rhun E, Besse B. Leptomeningeal carcinomatosis in non-small cell lung cancer patients: a continuing challenge in the personalized treatment era. Cancer Treat Rev 2017;53:128-37.

[2] Kuiper JL, Hendriks LE, van der Wekken AJ, de Langen AJ, Bahce I, Thunnissen E, et al. Treatment and survival of patients with EGFR-mutated non-small cell lung cancer and leptomeningeal metastasis: a retrospective cohort analysis. Lung Cancer 2015;89:255-61.

[3] NCCN guidelines central nervous system cancers version 1.2018. 2018.

[4] Le Rhun E, Weller M, Brandsma D, Van den Bent M, de Azambuja E, Henriksson R, et al. EANO-ESMO Clinical Practice Guidelines for diagnosis, treatment and follow-up of patients with leptomeningeal metastasis from solid tumours. Ann Oncol : Off J European Soc Med Oncol/ESMO 2017;28:iv84-99.

[5] Cheng H, Perez-Soler R. Leptomeningeal metastases in nonsmall-cell lung cancer. Lancet Oncol 2018;19:e43-55.

[6] Umemura S, Tsubouchi K, Yoshioka H, Hotta K, Takigawa N, Fujiwara K, et al. Clinical outcome in patients with leptomeningeal metastasis from non-small cell lung cancer: okayama Lung Cancer Study Group. Lung Cancer 2012;77:134-9.

[7] Planchard D, Popat S, Kerr K, Novello S, Smit EF, FaivreFinn C, et al. Metastatic non-small cell lung cancer: ESMO Clinical Practice Guidelines for diagnosis, treatment and followup. Ann Oncol : Off J European Soc Med Oncol/ESMO 2018;29: iv192-237.
[8] Antonia SJ, Villegas A, Daniel D, Vicente D, Murakami S, Hui R, et al. Overall survival with durvalumab after chemoradiotherapy in stage III NSCLC. N Engl J Med 2018:2342-50.

[9] Dudnik E, Yust-Katz S, Nechushtan H, Goldstein DA, Zer A, Flex D, et al. Intracranial response to nivolumab in NSCLC patients with untreated or progressing CNS metastases. Lung Cancer 2016;98:114-7.

[10] Gion M, Remon J, Caramella C, Soria JC, Besse B. Symptomatic leptomeningeal metastasis improvement with nivolumab in advanced non-small cell lung cancer patient. Lung Cancer 2017; 108:72-4.

[11] Brastianos P, Prakadan S, Alvarez-Breckenrdige C, Quant Lee E, Tolaney S, Nayak L, et al. Phase II study of pembrolizumab in leptomeningeal carcinomatosis. J Clin Oncol 2018;26. abstr 2007.

[12] Long GV, Atkinson V, Lo S, Sandhu S, Guminski AD, Brown MP, et al. Combination nivolumab and ipilimumab or nivolumab alone in melanoma brain metastases: a multicentre randomised phase 2 study. Lancet Oncol 2018;19:672-81.

[13] Geukes Foppen MH, Brandsma D, Blank CU, van Thienen JV, Haanen JB, Boogerd W. Targeted treatment and immunotherapy in leptomeningeal metastases from melanoma. Ann Oncol : Off J European Soc Med Oncol/ESMO 2016;27:1138-42.

[14] Chamberlain M, Junck L, Brandsma D, Soffietti R, Ruda R, Raizer J, et al. Leptomeningeal metastases: a RANO proposal for response criteria. Neuro Oncol 2017;19:484-92.

[15] Gandhi L, Rodriguez-Abreu D, Gadgeel S, Esteban E, Felip E, De Angelis F, et al. Pembrolizumab plus chemotherapy in metastatic non-small-cell lung cancer. N Engl J Med 2018;378:2078-92. 